\title{
An investigation on Implementation of Quality Management System to Improve Organizational Performance in Manufacturing Industry: Delhi-NCR Perspective
}

\author{
Jitesh Pandey ${ }^{1}$ \\ Department of Industrial Engg.\& Management \\ Takshshila Institute of Engineering \& Technology Jabalpur (M.P.) \\ Prof. Alok Agrawal ${ }^{2}$ \\ Department of Mechanical Engineering \\ Takshshila Institute of Engineering \& Technology Jabalpur (M.P.)
}

\begin{abstract}
The interference of Quality Management practices has brought excellent impact on the developing organizational endeavors. Previous researches have indicated that when quality management practices are applied, positive effects within the organizational networking can attest to its establishment. It is essential for the organization to implement Quality Management Interventions to attain competitive control; externally and internally. The objective of the study is; to investigate quality management practices and its impact on organizational performance of manufacturing firms among manufacturing industry in India. The research design used was descriptive survey method. The data collected comprised of primary data that was both quantitative and qualitative. Both descriptive and inferential statistics was used to analyze the data. From the findings all activities show that customer focus practices have been adopted in the respective organizations at large extent. This study recommends that manufacturing firms should consider adopting and implementing other quality management practices and compare the benefits and the challenges of these quality management practices. This will provide a better platform of choosing the quality management practices that lead to improved organizational performance. The study also recommends that manufacturing firms in India should benchmark themselves with the best performing firms globally in order to find out the quality management practices that the firms use in enhancing competitiveness. This will shed more light on the best quality management practices to adapt to increase organizational performance.
\end{abstract}

Keywords: Quality Management Practices, Organizational Performance, Manufacturing Industries, Statistical Analysis, Chi-square test for Independence, ISO Standard.

\section{Introduction}

The interference of quality management practices has brought excellent impact on the developing organizational endeavors. Previous researches have indicated that when quality management practices are applied, positive effects within the organizational networking can attest to its establishment. Quality management is any practice that produces better products while decreasing cost and increasing consumer satisfaction levels. Customer satisfaction is usually defined as post purchase of product comparison in between performance expected and expectation before purchase. The intervention of quality management practices in the organizations is imperative as augmentation of Human Resource practices lead to an enhanced organizational performance.

The expected results of quality management are better organizational performance, enhanced productivity, efficient processes and competitive goods and services that satisfy the consumer and enhance the organizational competiveness. Organizational performance stands out as the 
most critical variable in the administration look into and without a doubt the most imperative pointer of hierarchical achievement.

Quality management has gained prominence in the recent past as it directly impacts on the overall performance of manufacturing organizations. Quality has been noted to affect the whole organization and comes with a dramatic cost implication. Poor quality becomes a big problem when it leads to dissatisfied customers and eventually leads to loss of customers. From an academic point of view, quality management has been adopted by firms keen on leveraging their overall performance. Thus key decision makers within a given organization should incline their operational tendencies towards quality management practices for enhanced performance.

\subsection{Manufacturing Industry in India}

Manufacturing has emerged as one of the high growth sectors in India. India is expected to become the fifth largest manufacturing country in the world by the end of year 2020 .

The Gross Value Added (GVA) at basic current prices from the manufacturing sector in India grew at a CAGR of 4.34 per cent during FY12 and FY18 as per the second advance estimates of annual national income published by the Government of India. Quarterly GVA at basic prices from manufacturing sector grew by 10.92 per cent in the third quarter of FY18. Under the Make in India initiative, the Government of India aims to increase the share of the manufacturing sector to the gross domestic product (GDP) to 25 per cent by 2022, from 16 per cent, and to create 100 million new jobs by 2022. Business conditions in the Indian manufacturing sector continue to remain positive.

With the help of Make in India drive, India is on the path of becoming the hub for hi-tech manufacturing as global giants such as GE, Siemens, HTC, Toshiba, and Boeing have either set up or are in process of setting up manufacturing plants in India, attracted by India's market of more than a billion consumers and increasing purchasing power. Cumulative Foreign Direct Investment (FDI) in India's manufacturing sector reached US\$ 73.70 billion during April 2000-December 2017.

The Government of India has taken several initiatives to promote a healthy environment for the growth of manufacturing sector in the country. Some of the notable initiatives and developments are:

- As of March 2018, Government of India is in the process of coming up with a new industrial policy which envisions development of a globally competitive Indian industry.

- The government has introduced two new World Bank assisted projects viz. SANKALP scheme and STRIVE scheme for skill development in the country.

- In Union Budget 2018-19, the Government of India reduced the income tax rate to 25 per cent for all companies having a turnover of up to Rs 250 crore (US\$ 38.75 million).

- Under the Mid-Term Review of Foreign Trade Policy (2015-20), the Government of India increased export incentives available to labour intensive MSME sectors by 2 per cent.

- The Ministry of Electronics and Information Technology is in the process of formulation of a new electronics manufacturing policy. The aim of the new policy will be to create an ecosystem of manufacturing in the country, enable India to become a significant global player in some of these categories.

- Ministry of Home Affairs liberalised Arms Rules to boost 'Make in India' manufacturing policy of the government. The liberalisation of the policy is expected to encourage investment in the manufacturing of arms and ammunition and weapon systems and promote employment generation. 
- The Government of India has launched a phased manufacturing programme (PMP) aimed at adding more smartphone components under the Make in India initiative thereby giving a push to the domestic manufacturing of mobile handsets.

- The Government of India is in talks with stakeholders to further ease foreign direct investment (FDI) in defence under the automatic route to 51 per cent from the current 49 per cent, in order to give a boost to the Make in India initiative and to generate employment.

- The Ministry of Defence, Government of India, approved the "Strategic Partnership" model which will enable private companies to tie up with foreign players for manufacturing submarines, fighter jets, helicopters and armoured vehicles.

- The Union Cabinet has approved the Modified Special Incentive Package Scheme (MSIPS) in which, proposals will be accepted till December 2018 or up to an incentive commitment limit of Rs. 10,000 crore (US $\$ 1.5$ billion).

The manufacturing sector of India has the potential to reach US\$ 1 trillion by 2025 and India is expected to rank amongst the top three growth economies and manufacturing destination of the world by the year 2020. The implementation of the Goods and Services Tax (GST) will make India a common market with a GDP of US\$2.5 trillion along with a population of 1.32 billion people, which will be a big draw for investors.

\subsection{Research Problem}

Previous studies have not provided adequate evidence on the relationship between quality management practices and organizational performance of manufacturing firms. This study aimed to answer the question is there a significant relationship between quality management and performance of firms in Indian manufacturing industry?

\subsection{Research Objectives}

1. To establish quality management practices among manufacturing firms in Delhi-NCR.

2. To establish the performance of firms in manufacturing industry in Delhi-NCR.

3. To establish the relationship between quality management and performance of firms in the manufacturing industry in Delhi-NCR.

\subsection{Importance of the Study}

The study will have significant value for policy makers and development partners who lend a hand in the growth of private sector programs that contribute to a diversified and productive manufacturing industry. With regards to quality and performance, policies and regulations will be implemented to boost and stimulate both factors. This stands to benefit the managers of manufacturing firms who are the key players in organizational performance.

\section{Literature Survey}

Jane Bourke et al (2017) highlight the short term disruptive and longer-term beneficial effects of QIM adoption on product innovation performance. Results suggest that maximizing the returns to innovation and quality improvement requires consideration of the soft and/or hard nature of individual QIMs and the timing and sequencing of their adoption [5].

Young Sik Cho et al (2017) empirically examines the relationship between technical and behavioral quality practices by collecting survey data from both US-based and China-based firms. The analysis uses the structural equation modeling technique, and shows that behavioral QM practices fully mediate the relationship between technical QM practices and firm performance [11].

Luis Miguel Fonseca et al (2017) highlights the need for the automotive industry OEM and Suppliers to properly monitor the organizational (internal and external) context and identify 
the key issues that affect the ability of their QMS to deliver quality products, and to plan, design, implement and control change in an effective and timely manner, within the whole supply chain [6].

Guangfan Gao et al (2017) established a comprehensive quality evaluation system by adopting a hierarchical analytic process [3].

Sudeshna Roy et al (2017) identified the factors governing the quality of newly developed products to recognize the importance of control over the product quality in Indian manufacturing industries. The Structural Equation Modeling (SEM) approach has been used to build a causal relationship between success factors and measures by using AMOS 5.0 software package along with SPSS [9].

Wafi Al-Karaghouli et al (2016) provided empirical evidence leading to advancement in the understanding of direct and indirect influences of IRFC components on TQM implementation [4].

Vanajah Siva et al (2016) reviewed research in which Quality Management methods, tools or practices have been used in conjunction with sustainable development initiatives. They have identified four themes that synthesize the research on Quality Management and its support to approaches for sustainable development: (I) supporting sustainability through integration of management systems, (II) Quality Management as support to the implementation of Environmental Management Systems and to the management of sustainability, (III) supporting integration of sustainability considerations in daily work, and (IV) supporting stakeholder management and customer focus [10].

Rajesh Kumar Jain et al (2015) undertook a pragmatic study on the Real Quality Practices of Gujarat based Manufacturing Industries. The outcome of this research will help gauge the level of Quality Practices which also may lead to the suggestive steps to be implemented by other Organizations in the Country as a whole [8].

Marcello Colledani et al (2014) proposed Production quality as a new paradigm aiming at going beyond traditional six-sigma approaches. This new paradigm is extremely relevant in technology intensive and emerging strategic manufacturing sectors [7].

Frank Wiengarten et al (2012) investigated the importance of quality management practices for the success of environmental management initiatives. The study makes significant contributions to the quality and sustainability literature and implications are drawn to practice [2].

Dongli Zhang et al (2012) investigated how contextual factors influence the relationship between Quality Management (QM) practices and manufacturing performance. It contributes to the contingency theory of QM effectiveness. The analysis empirically investigates the internal fit with organizational structure and the external fit with environmental uncertainty on the relationship between Quality Exploration, Quality Exploitation, and operational performance. The findings provide insights for managers on how to customize QM programs to achieve optimal performance benefits [1].

\section{Research Design}

According to the All India Association of Industries (AIAI) manufacturing firms in India operating in different sectors are classified into 12 sub categories which are based on the raw materials that the companies import or the products that they manufacture. The large percentage of manufacturing industries of India is based on Delhi-NCR. Thus Delhi-NCR presented a suitable study area as large numbers of the manufacturing organizations are located in it.

A sample of 60 manufacturing firms from 8 sub categories in Delhi-NCR was selected for the research study. This study ensured that the selected sample was a representative of the 
manufacturing firms in the County. This is crucial as it allowed for the making of valid inferences such that the conclusions that were drawn reflected the entire population.

\section{Quality Management}

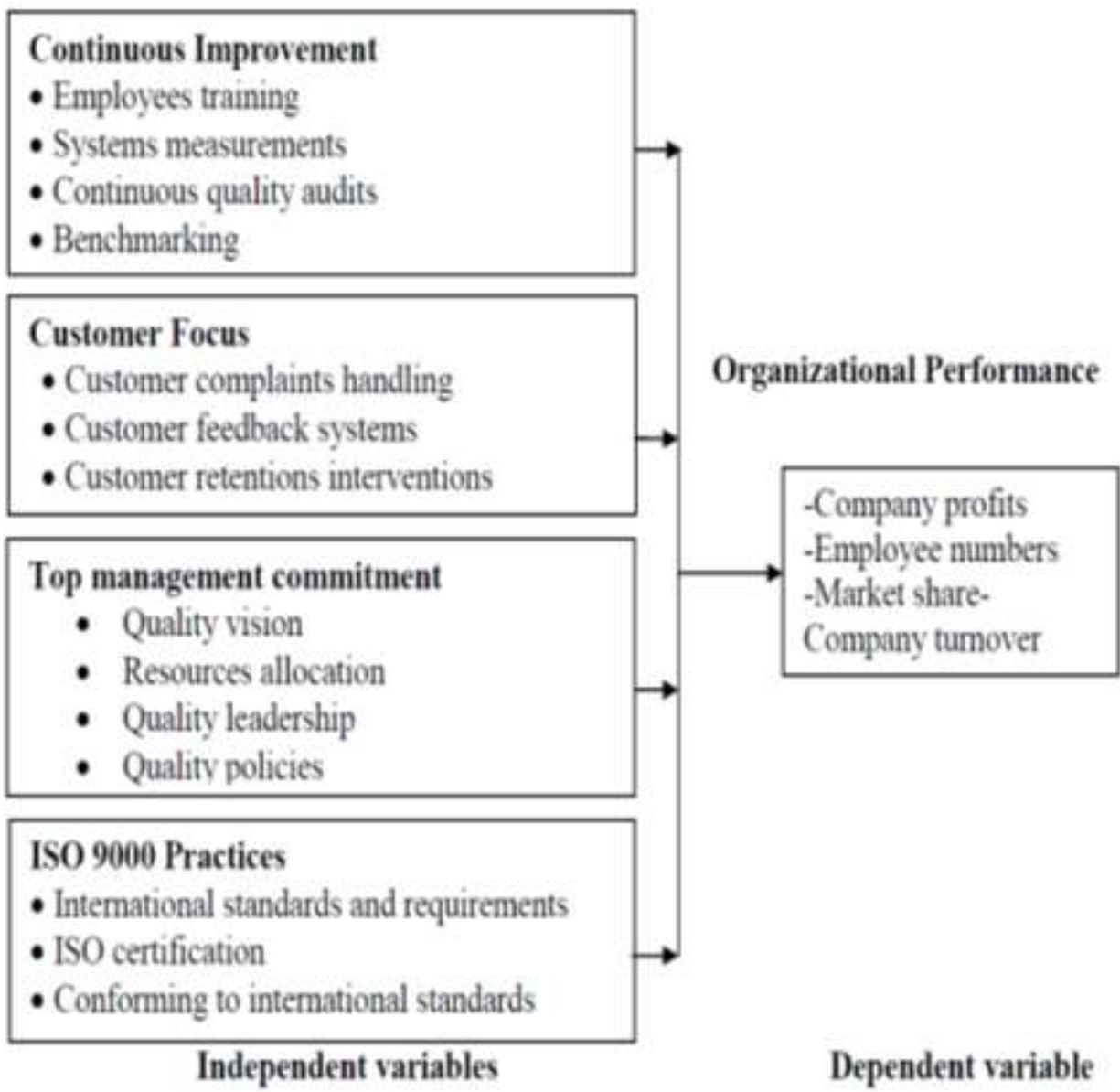

Figure: Conceptual Framework of QM

\subsection{Data Collection}

The data collected comprised of primary data that was both quantitative and qualitative. As a means of creating measures for the study geared towards an investigation of the research topic as well as the objectives, the study used a self-administered structured online survey questionnaire prepared in Google Form as the main tool for collecting data. This questionnaire is described in Appendices.

The questionnaire was divided into two sections; Section A contained background data, while section B contained quality management practices and its impact on organizational performance. The content of the structured questionnaire are designed as multiple choice questions based on 5-point Likert scales and also the use of scripted introduction and order of questions as per the research objectives.

Quality assurance manager was considered appropriate respondents for the study hence the questionnaire was administered to them. The online survey questionnaire was administered through emails and social networking. 


\begin{tabular}{|c|c|}
\hline 3.2 $\quad$ Parameters & \\
\hline $\begin{array}{c}\text { Quality Management } \\
\text { Parameters }\end{array}$ & Variables \\
\hline \multirow{8}{*}{$\begin{array}{l}\text { Continuous } \\
\text { Improvement }\end{array}$} & Training Policies \\
\hline & Employee Development Programs \\
\hline & Efficient Quality Improvement System \\
\hline & Quality Management Benchmarking \\
\hline & Efficient Product Delivery System \\
\hline & Regular Quality Audits \\
\hline & Internal Quality Feedback System \\
\hline & Improved Quality Policy \\
\hline \multirow{6}{*}{ Customer Focus } & Customer Feedback Mechanism \\
\hline & Customer Care Services \\
\hline & Customer Retention Policies \\
\hline & Customer Demand Management System \\
\hline & Regular Marketing Survey \\
\hline & Customer Needs Benchmarking \\
\hline \multirow{8}{*}{$\begin{array}{l}\text { Top Management } \\
\text { Commitment }\end{array}$} & Company Vision \\
\hline & Review of QMS Effectiveness \\
\hline & Financial Support for System Development \\
\hline & Quality Policy Support \\
\hline & Quality Policy Reviews and Improvement \\
\hline & Quality Team Leadership \\
\hline & Commitment for Quality Improvement \\
\hline & Recognition for Quality Improvement Efforts \\
\hline \multirow{6}{*}{ ISO 9000 Practices } & Follow-up for International Standards \\
\hline & International Standards Certification \\
\hline & Prevention of Non-conformity \\
\hline & ISO Certification Training \\
\hline & Effective Documentation of ISO \\
\hline & ISO Maintenance Programs \\
\hline
\end{tabular}




\subsection{Tools for Hypotheses Testing}

Hypothesis testing is used to find out the possibility that a given hypothesis is true or not. The procedure of hypothesis testing involves these steps:

1. Plan the null hypothesis Ho (i.e. the observations are the outcome of pure chance)

2. To evaluate the truth of the null hypothesis it is necessary to identify the statistical test.

For hypothesis testing the following statistical techniques are been used on the tabulated data.

- Reliability test:

- Normality test:

- Chi-Square test for Independence

\section{Data Analysis and Interpretation}

4.1 Demographic details of Respondents

\begin{tabular}{|c|c|c|}
\hline \multicolumn{3}{|c|}{ Gender of Respondents working in Organization } \\
\hline Gender & Frequency & Percentage \\
\hline Male & 48 & $80 \%$ \\
\hline Female & 12 & $20 \%$ \\
\hline Total & 60 & $100 \%$ \\
\hline \multicolumn{3}{|c|}{ Age Group of Respondents (In Years) } \\
\hline Age Group & Frequency & Percentage \\
\hline 18-25 Years & 4 & $6.67 \%$ \\
\hline 26-35 Years & 28 & $46.67 \%$ \\
\hline $36-45$ Years & 22 & $36.67 \%$ \\
\hline Above 45 Years & 6 & $10 \%$ \\
\hline Total & 60 & $100 \%$ \\
\hline \multicolumn{3}{|c|}{ Work Experience of Respondents (In Years) } \\
\hline Experience & Frequency & Percentage \\
\hline Below 1 year & 3 & $5 \%$ \\
\hline $1-5$ years & 9 & $15 \%$ \\
\hline 6-10 Years & 15 & $25 \%$ \\
\hline $11-15$ Years & 18 & $30 \%$ \\
\hline 15-20 Years & 9 & $15 \%$ \\
\hline More Than 20 Years & 6 & $10 \%$ \\
\hline Total & 60 & $100.00 \%$ \\
\hline \multicolumn{3}{|c|}{ Educational Qualification of Respondents } \\
\hline Qualification & Frequency & Percentage \\
\hline SSC or below & 02 & $3.33 \%$ \\
\hline Diploma & 09 & $15 \%$ \\
\hline Graduate & 21 & $35 \%$ \\
\hline PG or above & 28 & $46.67 \%$ \\
\hline Total & 60 & $100 \%$ \\
\hline \multicolumn{3}{|c|}{ Job Designation of Respondents } \\
\hline Designation & Frequency & Percentage \\
\hline Civil works & 06 & $10 \%$ \\
\hline Mechanical & 18 & $30 \%$ \\
\hline Electrical & 12 & $20 \%$ \\
\hline
\end{tabular}




\begin{tabular}{|c|c|c|}
\hline Materials & 15 & $25 \%$ \\
\hline Finance & 09 & $15 \%$ \\
\hline Total & 60 & $100 \%$ \\
\hline \multicolumn{3}{|c|}{ Employment Status of Respondents } \\
\hline Employment & Frequency & Percentage \\
\hline Permanent & 42 & $70 \%$ \\
\hline Temporary & 3 & $5 \%$ \\
\hline Contractual & 15 & $25 \%$ \\
\hline Total & 60 & $100 \%$ \\
\hline \multicolumn{3}{|c|}{ Current market region of Organization } \\
\hline Market Region & Frequency & Percentage \\
\hline Local & 36 & $60.00 \%$ \\
\hline Regional & 15 & $25.00 \%$ \\
\hline International & 9 & $15.00 \%$ \\
\hline Total & 60 & $100.00 \%$ \\
\hline \multicolumn{3}{|c|}{ Type of Standardization in Organization } \\
\hline Standardization & Frequency & Percentage \\
\hline BIS & 3 & $5.00 \%$ \\
\hline ISO 9000 & 24 & $40.00 \%$ \\
\hline ISO 9001-2008 & 33 & $55.00 \%$ \\
\hline Total & 60 & $100.00 \%$ \\
\hline \multicolumn{3}{|c|}{ Size of Organization (No. of Employees) } \\
\hline No. of Employees & Frequency & Percentage \\
\hline Less than 100 & 9 & $15.00 \%$ \\
\hline Equal or more than 100 & 36 & $60.00 \%$ \\
\hline Equal or more than 1000 & 15 & $25.00 \%$ \\
\hline Total & 60 & $100.00 \%$ \\
\hline \multicolumn{3}{|c|}{ Type of Industry of Respondents } \\
\hline Industry & Frequency & Percentage \\
\hline Chemical & 6 & $10.00 \%$ \\
\hline Electrical / Energy & 4 & $6.67 \%$ \\
\hline Leather & 4 & $6.67 \%$ \\
\hline Machineries & 8 & $13.33 \%$ \\
\hline Rubber \& Plastic & 5 & $8.33 \%$ \\
\hline Paper \& Board & 10 & $16.67 \%$ \\
\hline Metal Fabrication & 12 & $20.00 \%$ \\
\hline Food Products & 11 & $18.33 \%$ \\
\hline Total & 60 & $100.00 \%$ \\
\hline
\end{tabular}




\subsection{Continuous Improvement}

\begin{tabular}{|c|l|c|c|}
\hline \multicolumn{4}{|c|}{ Reliability Statistics } \\
\hline S. No. & \multicolumn{1}{|c|}{ Factors } & Cronbach's Alpha & $\begin{array}{c}\text { Cronbach's Alpha } \\
\text { with missing item }\end{array}$ \\
\hline 1 & Training Policies & 0.813 & 0.772 \\
\hline 2 & Employee Development Programs & 0.813 & 0.813 \\
\hline 3 & $\begin{array}{l}\text { Efficient Quality Improvement } \\
\text { System }\end{array}$ & 0.813 & 0.808 \\
\hline 4 & $\begin{array}{l}\text { Quality Management } \\
\text { Benchmarking }\end{array}$ & 0.813 & 0.794 \\
\hline 5 & Efficient Product Delivery System & 0.813 & 0.771 \\
\hline 6 & Regular Quality Audits & 0.813 & 0.779 \\
\hline 7 & Internal Quality Feedback System & 0.813 & 0.769 \\
\hline 8 & Improved Quality Policy & 0.813 & 0.824 \\
\hline
\end{tabular}

It is clearly evident that Cronbach's Alpha is 0.813 , which indicates a high level of internal consistency for our scale with this specific sample. It is interpreted that the data collected from these Manufacturing Organization has been reliable.

\begin{tabular}{|c|l|c|c|c|}
\hline \multicolumn{5}{|c|}{ Descriptive Statistics } \\
\hline S. No. & \multicolumn{1}{|c|}{ Factors } & Mean & SD & Wt. \\
\hline 1 & Training Policies & 4.20 & 0.860 & 0.840 \\
\hline 2 & Employee Development Programs & 4.25 & 0.856 & 0.850 \\
\hline 3 & Efficient Quality Improvement System & 3.92 & 1.046 & 0.783 \\
\hline 4 & Quality Management Benchmarking & 4.17 & 0.785 & 0.833 \\
\hline 5 & Efficient Product Delivery System & 4.15 & 0.860 & 0.830 \\
\hline 6 & Regular Quality Audits & 4.38 & 0.904 & 0.877 \\
\hline 7 & Internal Quality Feedback System & 4.33 & 0.877 & 0.867 \\
\hline 8 & Improved Quality Policy & 4.18 & 0.813 & 0.837 \\
\hline
\end{tabular}

The descriptive statistics shown in the above table depicts the ranking of continuous improvement on selected parameters. Top three parameters highlighted in the table on which continuous improvement has major impact are: Regular Quality Audits, Internal Quality Feedback System and Employee Development Programs. 


\begin{tabular}{|c|l|c|c|c|}
\hline \multicolumn{5}{|c|}{ Pearson's Chi Square Test for Independence - Type of Industry } \\
\hline S. No. & \multicolumn{1}{|c|}{ Factors } & chi-sq & p-value & sig \\
\hline 1 & Training Policies & 41.848 & 0.045 & yes \\
\hline 2 & Employee Development Programs & 45.064 & 0.022 & yes \\
\hline 3 & Efficient Quality Improvement System & 42.897 & 0.036 & yes \\
\hline 4 & Quality Management Benchmarking & 42.654 & 0.038 & yes \\
\hline 5 & Efficient Product Delivery System & 44.709 & 0.024 & yes \\
\hline 6 & Regular Quality Audits & 43.235 & 0.033 & yes \\
\hline 7 & Internal Quality Feedback System & 42.218 & 0.041 & yes \\
\hline 8 & Improved Quality Policy & 45.052 & 0.022 & yes \\
\hline
\end{tabular}

The null hypothesis is accepted, since for all 8 operational factors the $\mathrm{p}$ value $<0.05$, that fulfills $95 \%$ confidence level of responses. It shows that there is no significant difference amongst the opinion of quality managers with different type of industry regarding the selected operational factors. Therefore impact of continuous improvement on all above mentioned factors is same with respect to the quality managers with different type of industry.

\subsection{Customer Focus}

\begin{tabular}{|c|l|c|c|}
\hline \multicolumn{4}{|c|}{ Reliability Statistics } \\
\hline S. No. & \multicolumn{1}{|c|}{ Factors } & Cronbach's Alpha & $\begin{array}{c}\text { Cronbach's Alpha } \\
\text { with missing item }\end{array}$ \\
\hline 1 & Customer Feedback Mechanism & 0.822 & 0.820 \\
\hline 2 & Customer Care Services & 0.822 & 0.769 \\
\hline 3 & Customer Retention Policies & 0.822 & 0.826 \\
\hline 4 & $\begin{array}{l}\text { Customer Demand Management } \\
\text { System }\end{array}$ & 0.822 & 0.773 \\
\hline 5 & Regular Marketing Survey & 0.822 & 0.788 \\
\hline 6 & Customer Demand Benchmarking & 0.822 & 0.773 \\
\hline
\end{tabular}

It is clearly evident that Cronbach's Alpha is 0.822 , which indicates a high level of internal consistency for our scale with this specific sample. It is interpreted that the data collected regarding customer focus from these Manufacturing Organization has been reliable.

\begin{tabular}{|c|l|c|c|c|}
\hline \multicolumn{5}{|c|}{ Descriptive Statistics } \\
\hline S.N. & \multicolumn{1}{|c|}{ Factors } & Mean & SD & Wt. \\
\hline 1 & Customer Feedback Mechanism & 4.050 & 0.910 & 0.810 \\
\hline 2 & Customer Care Services & 4.117 & 0.993 & 0.823 \\
\hline
\end{tabular}




\begin{tabular}{|c|l|c|c|c|}
\hline \hline 3 & Customer Retention Policies & 4.200 & 0.879 & 0.840 \\
\hline 4 & $\begin{array}{l}\text { Customer Demand Management } \\
\text { System }\end{array}$ & 3.867 & 1.065 & 0.773 \\
\hline 5 & Regular Marketing Survey & 4.250 & 0.950 & 0.850 \\
\hline 6 & Customer Demand Benchmarking & 3.950 & 1.048 & 0.790 \\
\hline
\end{tabular}

The descriptive statistics shown in the above table depicts the ranking of customer focus on selected parameters. Top three parameters highlighted in the table on which customer focus has major impact are: Regular Marketing Survey, Customer Retention Policies and Customer Care Services.

\begin{tabular}{|c|l|c|c|c|}
\hline \multicolumn{5}{|c|}{ Pearson's Chi Square Test for Independence - Type of Industry } \\
\hline S. No. & \multicolumn{1}{|c|}{ Factors } & chi-sq & p-value & sig \\
\hline 1 & Customer Feedback Mechanism & 41.934 & 0.044 & yes \\
\hline 2 & Customer Care Services & 44.262 & 0.026 & yes \\
\hline 3 & Customer Retention Policies & 43.516 & 0.031 & yes \\
\hline 4 & Customer Demand Management System & 45.181 & 0.021 & yes \\
\hline 5 & Regular Marketing Survey & 44.817 & 0.023 & yes \\
\hline 6 & Customer Demand Benchmarking & 44.221 & 0.026 & yes \\
\hline
\end{tabular}

The null hypothesis is accepted, since for all 6 operational factors the $\mathrm{p}$ value $<0.05$, that fulfills $95 \%$ confidence level of responses. It shows that there is no significant difference amongst the opinion of quality managers with different type of industry regarding the selected operational factors. Therefore impact of customer focus on all above mentioned factors is same with respect to the quality managers with different type of industry.

\subsection{Top Management Commitment}

\begin{tabular}{|c|l|c|c|}
\hline \multicolumn{3}{|c|}{ Reliability Statistics } \\
\hline S. N. & \multicolumn{1}{|c|}{ Factors } & Cronbach's Alpha & $\begin{array}{c}\text { Cronbach's Alpha } \\
\text { with missing item }\end{array}$ \\
\hline 1 & Company Vision & 0.813 & 0.794 \\
\hline 2 & Review of QMS Effectiveness & 0.813 & 0.777 \\
\hline 3 & $\begin{array}{l}\text { Financial Support for System } \\
\text { Development }\end{array}$ & 0.813 & 0.778 \\
\hline 4 & Quality Policy Support & 0.813 & 0.783 \\
\hline 5 & $\begin{array}{l}\text { Quality Policy Reviews and } \\
\text { Improvement }\end{array}$ & 0.813 & 0.810 \\
\hline 6 & Quality Team Leadership & 0.813 & 0.793 \\
\hline
\end{tabular}




\begin{tabular}{|c|l|c|c|}
\hline \hline 7 & Commitment for Quality Improvement & 0.813 & 0.822 \\
\hline 8 & $\begin{array}{l}\text { Recognition for Quality Improvement } \\
\text { Efforts }\end{array}$ & 0.813 & 0.771 \\
\hline
\end{tabular}

It is clearly evident that Cronbach's Alpha is 0.813 , which indicates a high level of internal consistency for our scale with this specific sample. It is interpreted that the data collected from these Manufacturing Organization regarding Top Management Commitment has been reliable.

\begin{tabular}{|c|c|c|c|c|}
\hline \multicolumn{5}{|c|}{ Descriptive Statistics } \\
\hline SN & Factors & Mean & SD & Wt. \\
\hline 1 & Company Vision & 4.17 & 0.785 & 0.833 \\
\hline 2 & Review of QMS Effectiveness & 4.15 & 0.860 & 0.830 \\
\hline 3 & Financial Support for System \\
Development & 4.38 & 0.904 & 0.877 \\
\hline 4 & Quality Policy Support & 4.33 & 0.877 & 0.867 \\
\hline 5 & Quality Policy Reviews and \\
Improvement & 4.18 & 0.813 & 0.837 \\
\hline 6 & Quality Team Leadership & 4.28 & 0.922 & 0.857 \\
\hline 7 & Commitment for Quality Improvement & 4.23 & 0.810 & 0.847 \\
\hline 8 & Recognition for Quality Improvement & 4.08 & 0.907 & 0.817 \\
\hline
\end{tabular}

The descriptive statistics shown in the above table depicts the ranking of Top Management Commitment on selected parameters. Top three parameters highlighted in the table on which Top Management Commitment has major impact are: Financial Support for System Development, Quality Policy Support and Quality Team Leadership.

\begin{tabular}{|c|l|c|c|c|}
\hline \multicolumn{5}{|c|}{ Pearson's Chi Square Test for Independence - Type of Industry } \\
\hline \multicolumn{1}{|c|}{ Factors } & chi-sq & p-value & sig \\
\hline S. No. & \multicolumn{1}{|c|}{ - } & 43.362 & 0.032 & yes \\
\hline 1 & Company Vision & 41.449 & 0.049 & yes \\
\hline 2 & Review of QMS Effectiveness & 47.541 & 0.012 & yes \\
\hline 3 & $\begin{array}{l}\text { Financial Support for System } \\
\text { Development }\end{array}$ & 43.814 & 0.029 & yes \\
\hline 5 & Quality Policy Support & 46.973 & 0.014 & yes \\
\hline 6 & $\begin{array}{l}\text { Quality Policy Reviews and } \\
\text { Improvement }\end{array}$ & 44.409 & 0.025 & yes \\
\hline 7 & Quality Team Leadership & 41.618 & 0.047 & yes \\
\hline 8 & $\begin{array}{l}\text { Recognition for Quality Improvement } \\
\text { Efforts }\end{array}$ & 44.043 & 0.028 & yes \\
\hline
\end{tabular}


The null hypothesis is accepted, since for all 8 operational factors the $p$ value $<0.05$, that fulfills $95 \%$ confidence level of responses. It shows that there is no significant difference amongst the opinion of quality managers with different type of industry regarding the selected operational factors. Therefore impact of Top Management Commitment on all above mentioned factors is same with respect to the quality managers with different type of industry.

\subsection{ISO Practices}

\begin{tabular}{|c|l|c|c|}
\hline \multicolumn{3}{|c|}{ Reliability Statistics } \\
\hline S. N. & \multicolumn{1}{|c|}{ Factors } & Cronbach's Alpha & $\begin{array}{c}\text { Cronbach's Alpha } \\
\text { with missing item }\end{array}$ \\
\hline 1 & $\begin{array}{l}\text { Follow-up for International } \\
\text { Standards }\end{array}$ & 0.815 & 0.774 \\
\hline 2 & $\begin{array}{l}\text { International Standards } \\
\text { Certification }\end{array}$ & 0.815 & 0.764 \\
\hline 3 & Prevention of Non-conformity & 0.815 & 0.762 \\
\hline 4 & ISO Certification Training & 0.815 & 0.829 \\
\hline 5 & Effective Documentation of ISO & 0.815 & 0.787 \\
\hline 6 & ISO Maintenance Programs & 0.815 & 0.792 \\
\hline
\end{tabular}

It is clearly evident that Cronbach's Alpha is 0.815 , which indicates a high level of internal consistency for our scale with this specific sample. It is interpreted that the data collected regarding ISO 9000 practices from these Manufacturing Organization has been reliable.

\begin{tabular}{|c|l|c|c|c|}
\hline \multicolumn{5}{|c|}{ Descriptive Statistics } \\
\hline $\begin{array}{c}|c| \\
\text { S. }\end{array}$ & \multicolumn{1}{|c|}{ Factors } & Mean & SD & Wt. \\
\hline & & & & \\
& Follow-up for International Standards & 4.17 & 0.827 & 0.833 \\
\hline 2 & International Standards Certification & 4.28 & 1.010 & 0.857 \\
\hline 3 & Prevention of Non-conformity & 4.23 & 0.998 & 0.847 \\
\hline 4 & ISO Certification Training & 4.17 & 0.942 & 0.833 \\
\hline 5 & Effective Documentation of ISO & 4.20 & 0.971 & 0.840 \\
\hline 6 & ISO Maintenance Programs & 3.98 & 0.983 & 0.797 \\
\hline
\end{tabular}

The descriptive statistics shown in the above table depicts the ranking of ISO 9000 practices on selected parameters. Top three parameters highlighted in the table on which ISO 9000 practices has major impact are: International Standards Certification, Prevention of Nonconformity and Effective Documentation of ISO. 


\begin{tabular}{|c|l|c|c|c|}
\hline \multicolumn{5}{|c|}{ Pearson's Chi Square Test for Independence - Type of Industry } \\
\hline S. N. & \multicolumn{1}{|c|}{ Factors } & chi-sq & $p$-value & sig \\
\hline 1 & Follow-up for International Standards & 44.759 & 0.023 & yes \\
\hline 2 & International Standards Certification & 43.867 & 0.029 & yes \\
\hline 3 & Prevention of Non-conformity & 44.800 & 0.023 & yes \\
\hline 4 & ISO Certification Training & 41.813 & 0.045 & yes \\
\hline 5 & Effective Documentation of ISO & 47.419 & 0.012 & yes \\
\hline 6 & ISO Maintenance Programs & 42.996 & 0.035 & yes \\
\hline
\end{tabular}

The null hypothesis is accepted, since for all 6 operational factors the $\mathrm{p}$ value $<0.05$, that fulfills $95 \%$ confidence level of responses. It shows that there is no significant difference amongst the opinion of quality managers with different type of industry regarding the selected operational factors. Therefore impact of ISO 9000 practices on all above mentioned factors is same with respect to the quality managers with different type of industry.

\section{Findings \& Conclusion}

Continuous quality improvement is practiced between a very large extent and large extent. Training policies for employees, employees are continuously trained to enhance internal quality performance, continuous improvement of quality systems leading to increased revenue, firms benchmarks its quality against other quality management practices best practices, set time limit to meet efficiency of products delivery, quality audits are carried out continuously as per ISO certification requirements, continuous improvement reviews through internal quality audits and policy for making continuous improvement of products quality for every individual in the company.

Customer focus practices have been adopted in the respective organizations at large extent. Mechanism for customer complaints handling, customer care employees are well trained as telephone customer care, company is committed to customer retention by ensuring quality products, customer needs and expectations are communicated throughout the company, the company conducts customer feedback surveys regularly and benchmarking with other company helps the company to measure performance progress.

Top management commitment practices have been adopted in the respective organizations at large extent. It was established that Quality management is embraced in the vision of the company had been adapted to large extent. It was also established that top management reviews organizations QMS at planned intervals to ensure continuity, adequacy and effectiveness and devotes resources for development and support for ISO certification. Finally it was established that top management establish trust and commitment to quality improvement by eliminating fear.

ISO 9000 practices have been adopted in the respective organizations at large extent. The respondents indicated that their firms observe international standards and requirements, is ISO certified and prevent non conformity.

The successful implementation of quality programs depends on workforce. If manufacturing industry would have more trained, involved and empowered employees it is more likely to realize benefits of implementation of quality management techniques. The findings of 
research study suggest that management of manufacturing industry should be more involved in quality improvement programs.

\section{References}

1. Dongli Zhang, Kevin Linderman, Roger G. Schroeder, "The moderating role of contextual factors on quality management practices", Journal of Operations Management, Vol. 30, p.p. 12-23 (2012)

2. Frank Wiengarten, MarkPagell, "The importance of quality management for the success of environmental management initiatives", Int. J. Production Economics, Vol. 140, p.p. 407-415 (2012)

3. Guangfan Gao, Heping $\mathrm{Wu}$, Liangliang Sun, Lixin $\mathrm{He}$, "Comprehensive quality evaluation system for manufacturing enterprises of large piston compressors", Global Congress on Manufacturing and Management, p.p. 566-570 (2017)

4. Haffar, M., Al-Karaghouli, W. Ghoneim, A. 2013. The mediating effect of individual readiness for change in the relationship between organisational culture and TQM implementation. Total Quality Management and Business Excellence. 24, 693-706.

5. Jane Bourke, Stephen Roper, "Innovation, quality management and learning: Short-term and longer-term effects", Research Policy, Vol. 46, p.p. 1505-1518 (2017)

6. Luis Miguel Fonseca, Jose Pedro Domingues, "Reliable and flexible Quality Management Systems in the automotive industry: monitor the context and change effectively", International Conference on Flexible Automation and Intelligent Manufacturing, p.p. 1200-1206 (2017)

7. Marcello Colledani, Tullio Tolio, Anath Fischer, Benoit Iung, Gisela Lanza, Robert Schmitt, Jozsef Vancza, "Design and management of manufacturing systems for production quality", CIRP Annals - Manufacturing Technology, p.p. 773-796 (2014)

8. Rajesh Kumar Jain, Abhimanyu Samrat, "A Study of Quality Practices of Manufacturing Industries in Gujarat", Annual International Conference of the Society of Operations Management, p.p. 320-334 (2015)

9. Sudeshna Roy, Nipu Modak, Pranab K Dan, "Product Quality as Factors and Measures for New Product Development Success in Indian Manufacturing Industries", International Conference of Materials Processing and Characterization, p.p. 1385-1393 (2017)

10. Vanajah Siva, Ida Gremyr, Bjarne Bergquist, Rickard Garvare, Thomas Zobel, Raine Isaksson, "The support of Quality Management to sustainable development: A literature review", Journal of Cleaner Production (2016)

11. Young Sik Cho, Joo Y. Jung, Kevin Linderman, "The QM Evolution: Behavioral Quality Management as a Firm's Strategic Resource", Intern. Journal of Production Economics (2017) 